\title{
Studi Potensi Air Tanah untuk Penanggulangan Bencana Asap di Kabupaten Kapuas
}

\author{
Hendra Wahyudi \\ Program Studi Diploma Teknik Sipil FTSP ITS \\ Email: hendra_w@ce.its.ac.id
}

\begin{abstract}
Indonesia has two seasons: the rainy and dry season, when the dry season, smoke and drought disasters often happend, it is because many land clearing and forest fires and peatland. One area that is often a forest fire is Kapuas district of Central Kalimantan.

Kapuas district based on Undang-Undang 5 of 2002 is a result of expansion in the district of Gunung Mas with a total area of $14999 \mathrm{~km}^{2}$ has a topography north in the form of a hilly area with a slope of $8^{\circ}-15^{\circ}$ while the south is an area of marshy swamp.

Kapuas is one of the mainstay of agriculture because almost $65 \%$ of rice production Central Kalimantan supplied from Kapuas, existing potential agricultural land area of 76.80 thousand hectares and there are 277 thousand hectares of land with the potential to be developed each year often appear smoke haze from land clearing.

This study looked at the potential of groundwater in Kapuas to overcome the haze problem by investigating geoelectric, to see the potential fo groundwater. The investigation geoelectric used to see the potential of groundwater in Kapuas with resistivity geoelectric method

Based on geoelectric mapping conducted in Kapuas on Batuah area, Lamunti, Dadahup, Bungai Jaya and Palingkau then the results can be used to overcome the haze even though its potential is very small between $0.3 \mathrm{l} / \mathrm{sec}$ up to $3 \mathrm{l} / \mathrm{sec}$.
\end{abstract}

Keywords: Kapuas district, Smoke, Potential Groundwater and Geolistrik

Abstrak

Indonesia mempunyai dua musim yaitu musim hujan dan kemarau, pada saat musim kemarau sering terjadi bencana asap dan kekeringan, hal ini disebabkan banyak dilakukan pembukaan lahan dan terjadinya kebakaran hutan dan lahan gambut. Salah satu daerah yang sering terjadi kebakaran hutan adalah daerah kabupaten Kapuas Provinsi Kalimantan Tengah.

Kabupaten Kapuas yang ada saat ini berdasarkan Undang undang nomer 5 tahun 2002 merupakan kabupaten hasil pemekaran dengan Kabupaten Gunung Mas dengan luas wilayah sebesar $14.999 \mathrm{~km}^{2}$ mempunyai kondisi topografi sebelah utara berupa daerah perbukitan dengan kemiringan $8^{\circ}-15^{\circ}$ sedangkan bagian selatan merupakan daerah rawa.

Kabupaten Kapuas ini merupakan salah satu daerah andalan sektor pertanian karena hampir 65\% produksi beras Kalimantan Tengah dipasok dari Kabupaten Kapuas, potensi lahan pertanian yang ada seluas 76,80 ribu hektar dan masih ada 277 ribu hektar lagi lahan yang potensial untuk dikembangkan, sehingga setiap tahun sering muncul bencana asap akibat pembukaan lahan.

Studi ini melihat potensi air tanah yang ada di Kabupaten Kapuas untuk mengatasi masalah kabut asap dengan melakukan penyelidikan geolistrik untuk melihat potensi air tanah yang ada. Penyelidikan geolisrik yang dipergunakan untuk melihat potensi air tanah yang ada di Kabupaten Kapuas dengan metode geolistrik resistivitas.

Berdasarkan pemetaan geolistrik yang dilakukan di Kabupaten Kapuas pada daerah Batuah, Lamunti, Dadahup, Bungai Jaya, dan Palingkau, maka hasilnya dapat dipergunakan untuk mengatasi kabut asap walaupun potensinya sangat kecil antara $0.3 \mathrm{l} / \mathrm{dt}$ sampai dengan $3 \mathrm{l} / \mathrm{dt}$.

Kata kunci: Kabupaten Kapuas, kabut asap, potensi air tanah, dan geolistrik.

\section{Pendahuluan}

Indonesia mempunyai dua musim yaitu musim hujan dan kemarau, pada saat musim kemarau sering terjadi bencana asap dan kekeringan, hal ini disebabkan banyak dilakukan pembukaan la- han dan terjadinya kebakaran hutan dan lahan gambut. Salah satu daerah yang sering kali terjadi kebakaran hutan adalah daerah kabupaten Kapuas Provinsi Kalimantan Tengah. 
Kabupaten Kapuas yang ada saat ini berdasarkan undang undang nomer 5 tahun 2002 merupakan kabupaten hasil pemekaran dengan Kabupaten Gunung Mas dengan luas wilayah sebesar $14.999 \mathrm{~km}^{2}$ mempunyai kondisi topografi sebelah utara berupa daerah perbukitan dengan kemiringan $8^{\circ}-15^{\circ}$ sedangkan bagian selatan merupakan daerah rawa.

Kabupaten Kapuas ini merupakan salah satu daerah andalan sektor pertanian karena hampir $65 \%$ produksi beras Kalimantan Tengah dipasok dari Kabupaten Kapuas, potensi lahan pertanian yang ada seluas 76,80 ribu hektar dan masih ada 277 ribu hektar lagi lahan yang potensial untuk dikembangkan sehingga setiap tahun sering muncul bencana asap akibat pembukaan lahan.

Untuk memadamkan kebakaran pada daerah yang jauh dari sumber air sering mengalami kesulitan sehingga perlu mencari sumber air yang baru salah satunya adalah air tanah. Potensi air tanah tidak menyebar merata tergantung dari penyebaran akuifernya, sehingga perlu dilakukan penelitian letak akuifer. Posisi akuifer dan jenis akuifernya dapat diketahui kemampuannya untuk menyimpan air tanah.

Permasalahan dalam penelitian ini yaitu diduga daerah Kapuas mempunyai potensi air tanah yang dapat dimanfaatkan untuk menanggulangi bahaya kebakaran, keandalan memprediksi dengan menggunakan geolistrik dapat dipergunakan untuk mengetahui lokasi akuifer yang mempunyai potensi menyimpan air tanah.

Batasan dalam penelitian ini yaitu hanya dilakukan pada Daerah Batuah, Lamunti, Dadahup, Bungai Jaya, dan Palingkau yang lokasinya jauh dari sungai. Penelitian ini hanya mempergunakan data geolistrik untuk interpreatsi akuifer yang mempunyai potensi air tanah.

Manfaat dan tujuan yang hendak dicapai dari kegiatan penelitian ini adalah sebagai berikut:

1. Penelitian ini jika dilihat dari sisi ilmu pengetahuan maka diharapkan dapat menambah khasanah ilmu pengetahuan khususnya masalah lahan pasang surut.

2. Hasil penelitian ini diharapkan dapat dijadikan sebagai pedoman dalam mengembangkan air tanah.

3. Hasil penelitian ini dapat dijadikan sebagai masukan bagi para pengambil kebijakan dalam memanfaatkan air tanah untuk mengatasi bencana asap.

\section{Metodologi}

Geolistrik resistivitas merupakan metode pendugaan struktur lapisan batuan bawah permukaan bumi berdasarkan nilai resistivitas setiap jenis batuan yang terukur saat diberikan arus listrik yang dimasukkan ke dalam bumi melalui 2 elektroda arus. Arus listrik yang mengalir melalui 2 elektroda menghasilkan beda potensial yang dapat diukur menggunakan dua elektroda potensial. Hasil pengukuran arus dan beda potensial setiap jarak elek- 
troda menghasilkan variasi harga hambatan jenis masing-masing lapisan batuan di bawah titik ukur.

Harga resistivitas untuk berbagai jenis batuan dapat dilihat pada Tabel 1 dan 2.

Tabel 1. Nilai Resistivitas Batuan

\begin{tabular}{lc}
\hline \multicolumn{1}{c}{ Material } & $\begin{array}{c}\text { Resistivity }(\mathrm{Ohm} \\
\text { meter })\end{array}$ \\
\hline Sedimentary Rock & $10-10^{3}$ \\
\hline Shale & $1-10^{9}$ \\
Sandstone & $50-10^{7}$ \\
Limestone & $10^{2}-10^{4}$ \\
Dolomite & $10^{2}-5.10^{4}$ \\
Lavas & $2.10^{1}-2.10^{2}$ \\
Tuffs & \\
\hline Unconsolidated & $1-10^{3}$ \\
Sediment & $1-10^{2}$ \\
\hline Sand & $1-10^{2}$ \\
Clay & \\
Marl & $0,1-10^{3}$ \\
\hline Groundwater & $0,2-1$ \\
\hline Portable well water & 0,2 \\
Brackish water & $0,5-0,2$ \\
Sea water & Shd Sheriff, \\
Supersaline brine & Geldart \\
1976 & amber: Telford,
\end{tabular}

Tabel 2. Nilai Resistivitas Batuan

\begin{tabular}{lc}
\hline \multicolumn{1}{c}{ Jenis batuan } & $\begin{array}{c}\text { Resistivitas } \\
\text { (Ohm.meter) }\end{array}$ \\
\hline Gambut dan lempung & $8-50$ \\
Lempung pasiran dan lapisan & $40-250$ \\
Kerikil & $40-100$ \\
$\begin{array}{l}\text { Pasir dan kerikil jenuh } \\
\text { Batu lempung, napal dan serpih } \\
\text { Batu pasir dan batu kapur } \\
\text { (breksi) }\end{array}$ & $800-3000$ \\
$\begin{array}{l}\text { Sumber: Verhoef, 1994 } \\
\text { Menurut Robinson (1988), }\end{array}$ & interpretasi \\
$\begin{array}{l}\text { dari pengukuran geolistrik } \\
\text { resistivitas }\end{array}$
\end{tabular}

didasarkan pada anggapan-anggapan sebagai berikut:

1. Bawah permukaan tanah terdiri dari beberapa lapisan yang dibatasi oleh bidang batas horisontal serta terdapat kontras resistivitas antara bidang batas per lapisan tersebut.

2. Lapisan bumi bersifat homogen isotropik dan mempunyai ketebalan tertentu, kecuali untuk lapisan terbawah mempunyai ketebalan yang tidak terjangkau.

3. Batas antara dua lapisan merupakan bidang batas antara dua resistivitas yang berbeda.

4. Di dalam bumi tidak ada sumber listrik lain selain listrik searah (DC) yang diinjeksikan di atas permukaan bumi.

Metode penelitian merupakan langkah penelitian yang dilakukan mulai awal sampai akhir sehingga dapat diambil suatu kesimpulan. Adapun langkah untuk pemetaan geolistrik dengan metode resistivitas konvigurasi Schlumberger ini memakai 4 elektroda, masing-masing 2 elektroda arus dan 2 elektroda potensial seperti terlihat pada Gambar 1.

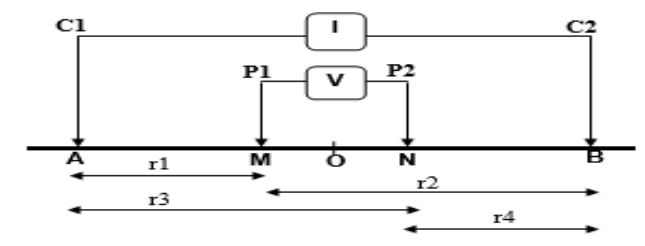

Gambar 1. Konfigurasi Schlumberger

\section{Hasil dan Pembahasan}

Hasil pengukuran geolistrik yang dilakukan di Kabupaten Kapuas pada daerah Batuah, Lamunti, Dadahup, Bungai Jaya, dan Palingkau dapat dilihat pada Tabel $1-14$. 
Tabel 1. Hasil Pengukuran Geolistrik Daerah Batuah (BTH1)

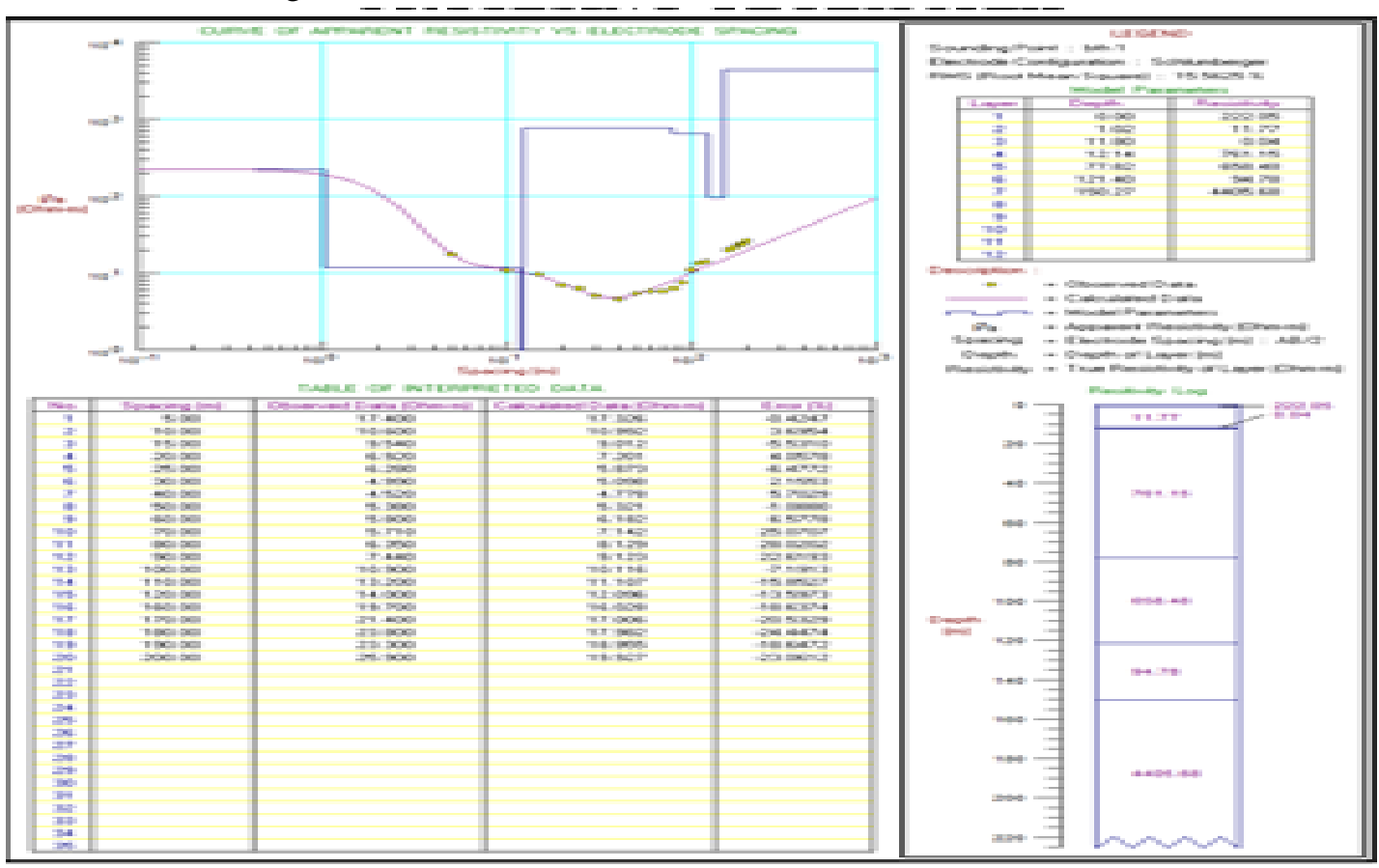

Tabel 2. Hasil Pengukuran Geolistrik Daerah Batuah (BTH2)

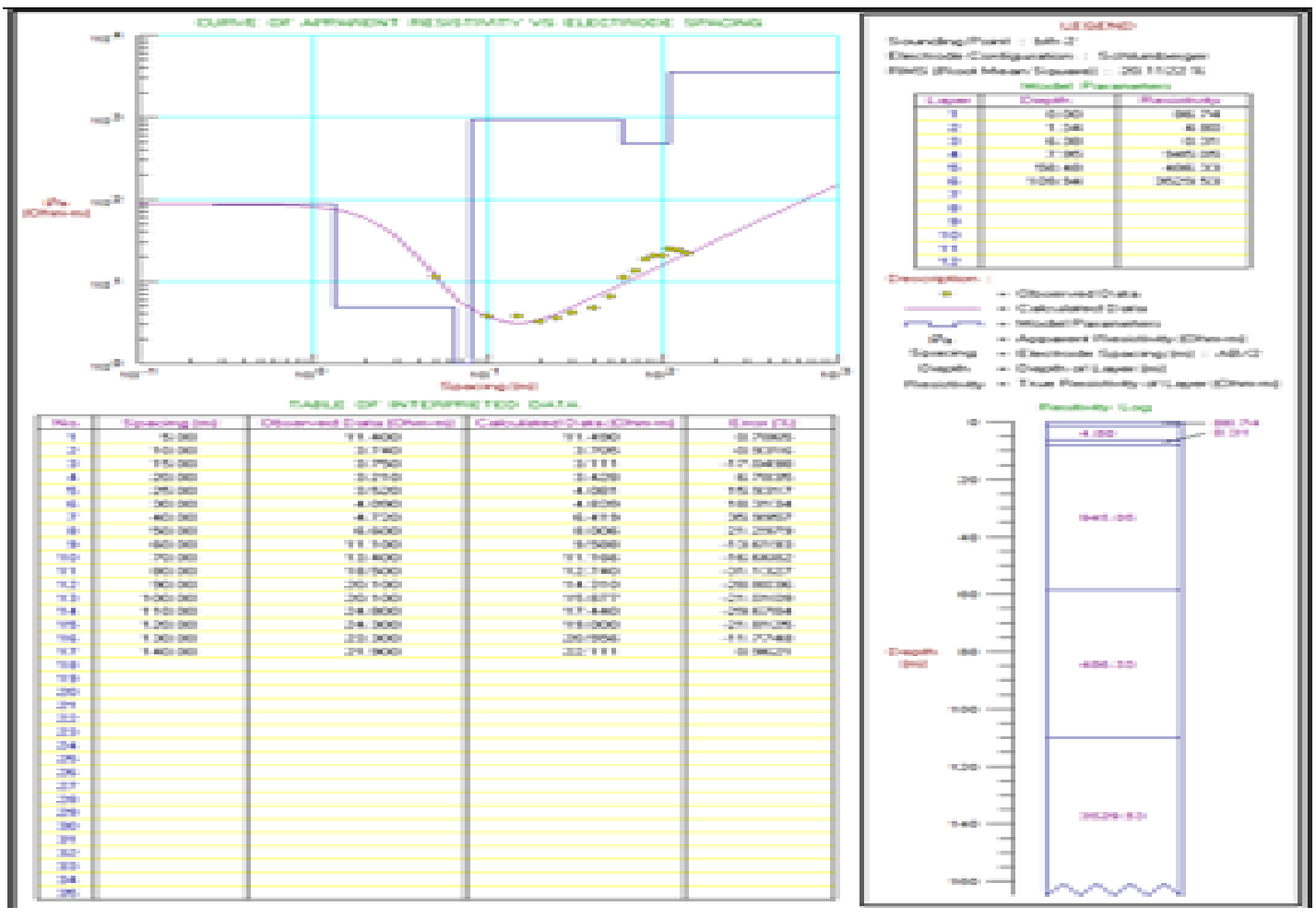


Jurnal Aplikasi Teknik Sipil ISSN.1907-753X

Tabel 3. Hasil Pengukuran Geolistrik Daerah Lamunti B2-1

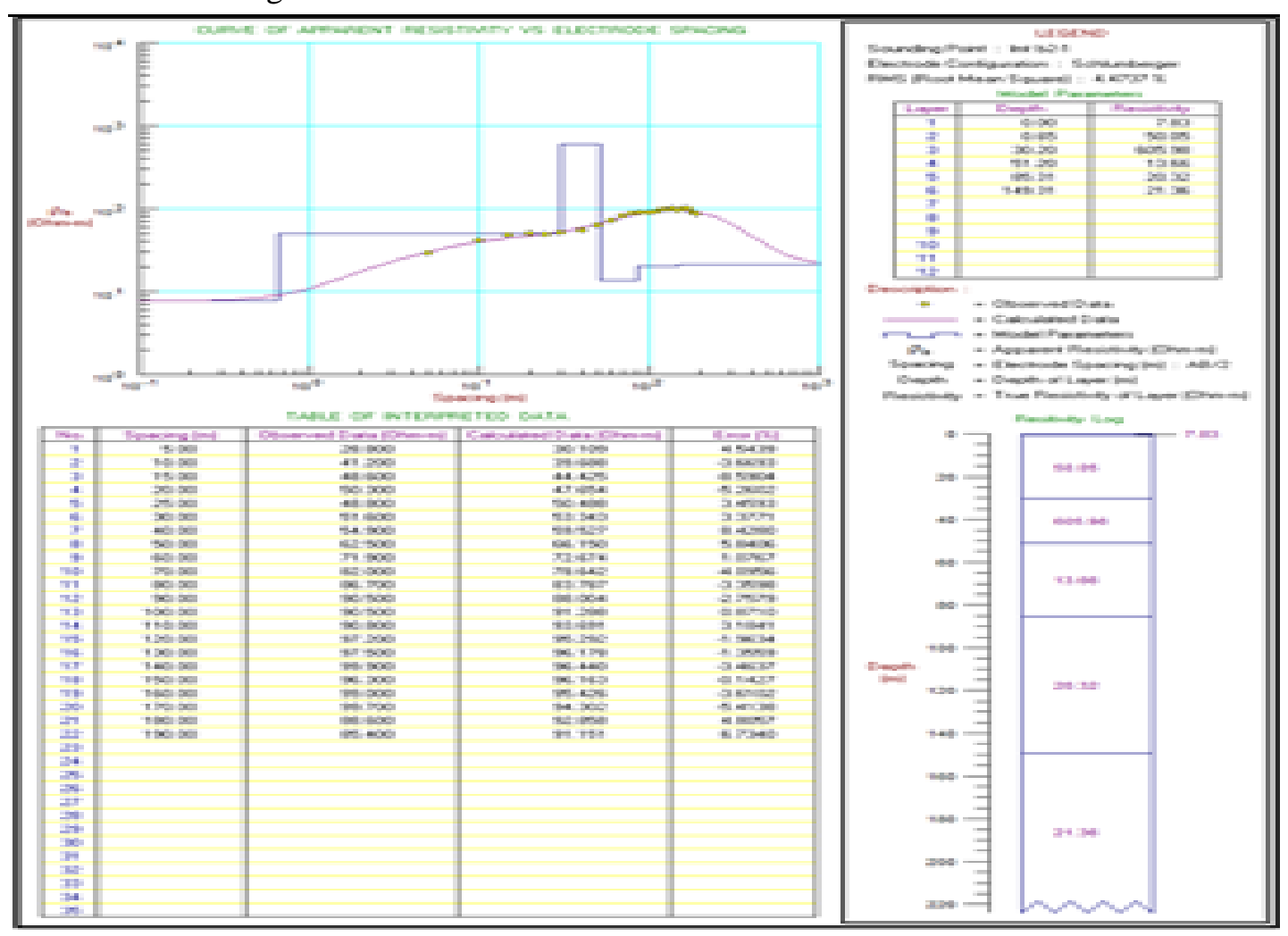

Tabel 4. Hasil Pengukuran Geolistrik Daerah Lamunti B2-2

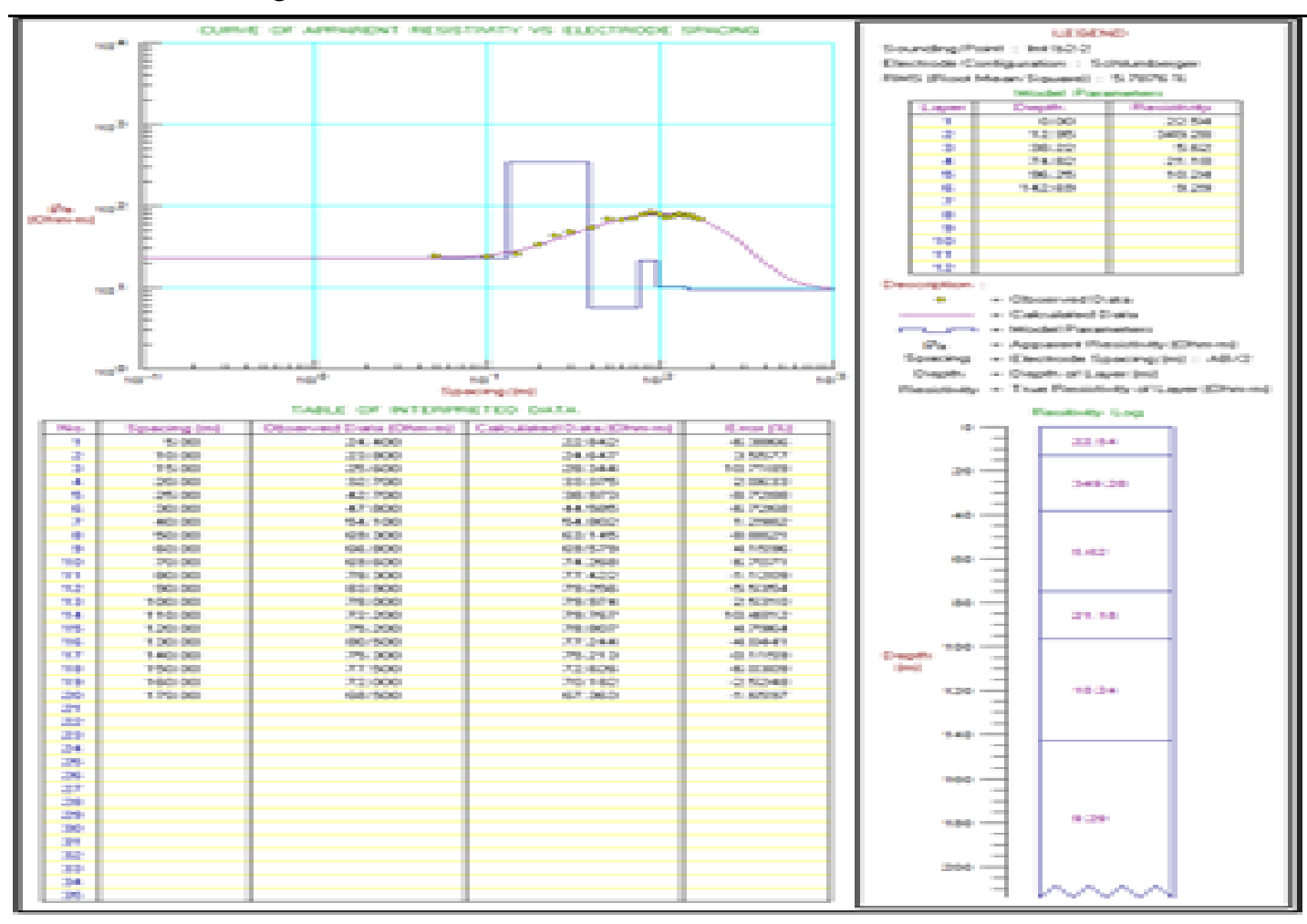


Tabel 5. Hasil Pengukuran Geolistrik Daerah Lamunti A2-1

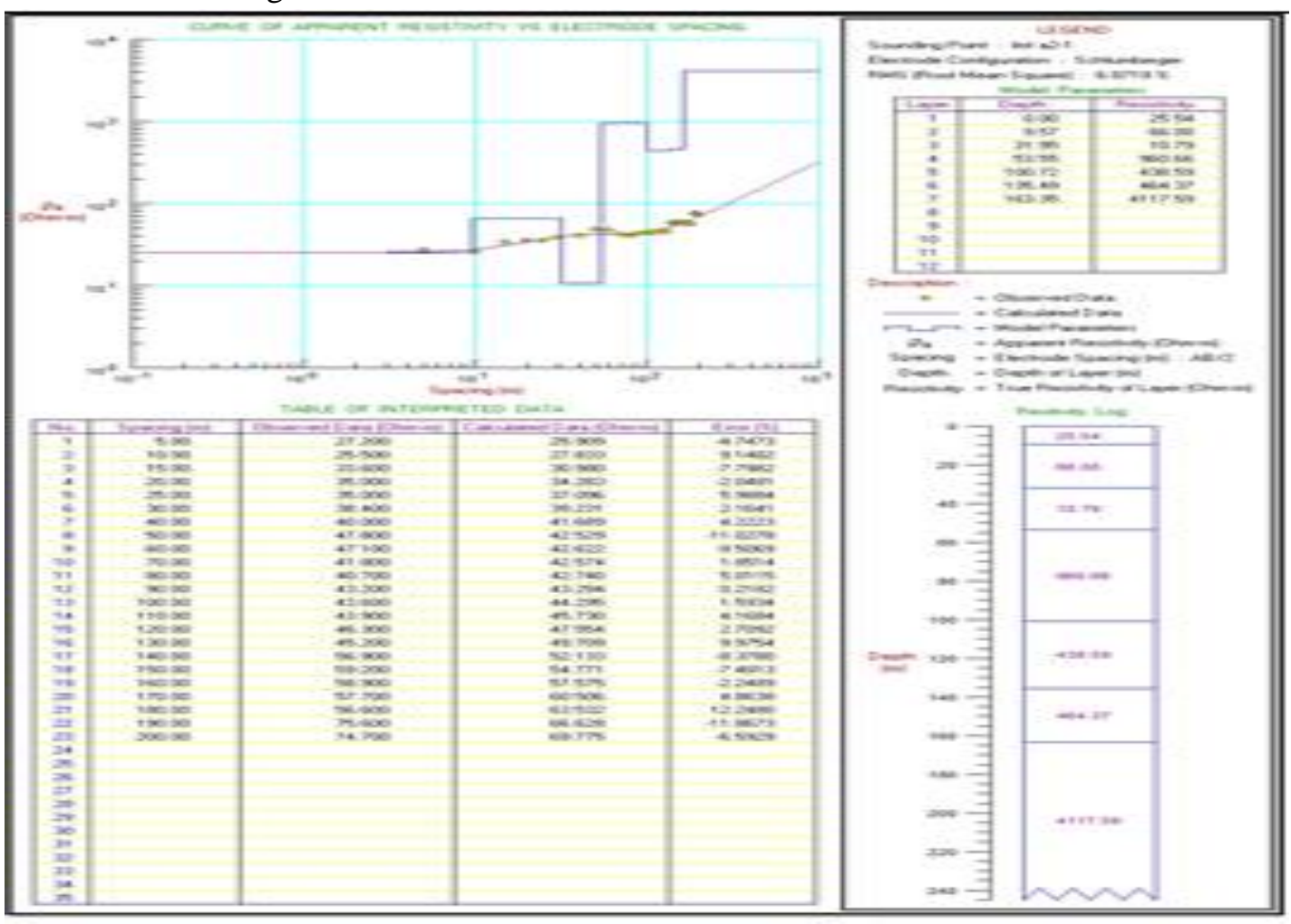

Tabel 6. Hasil Pengukuran Geolistrik Daerah Lamunti A2-2

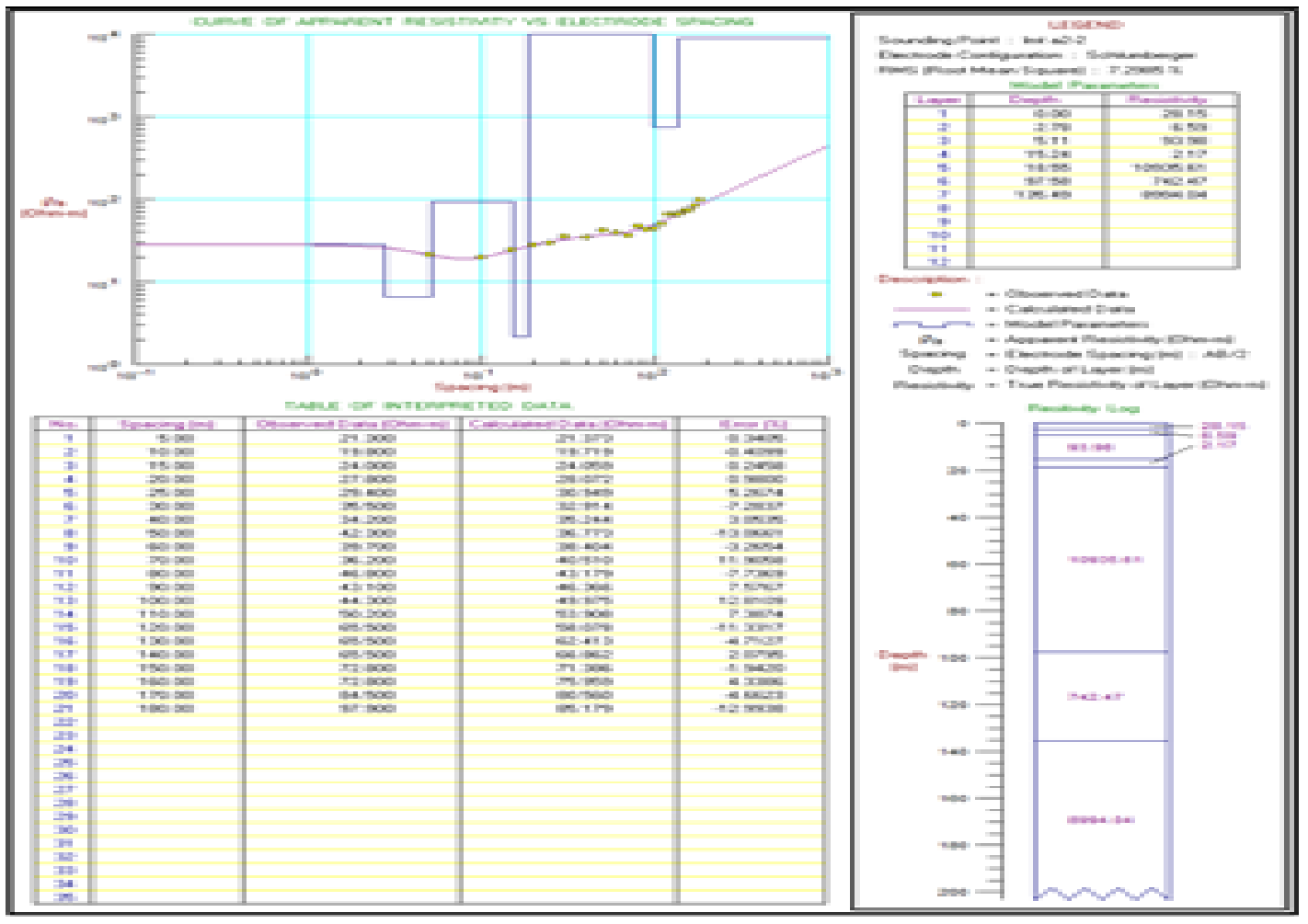


Jurnal Aplikasi Teknik Sipil ISSN.1907-753X

Tabel 7. Hasil Pengukuran Geolistrik Daerah Lamunti B1-1

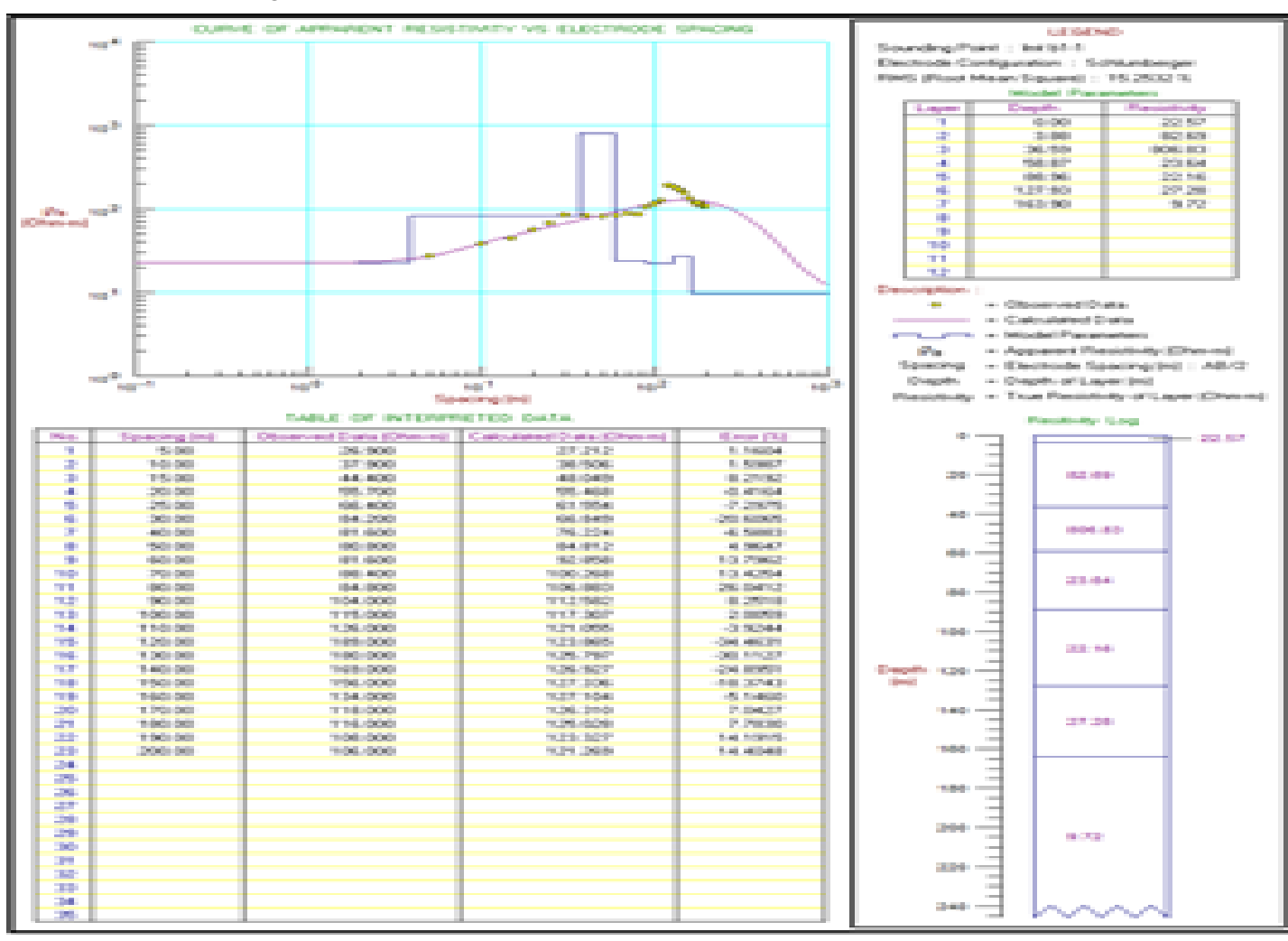

Tabel 8. Hasil Pengukuran Geolistrik Daerah Lamunti B1-2

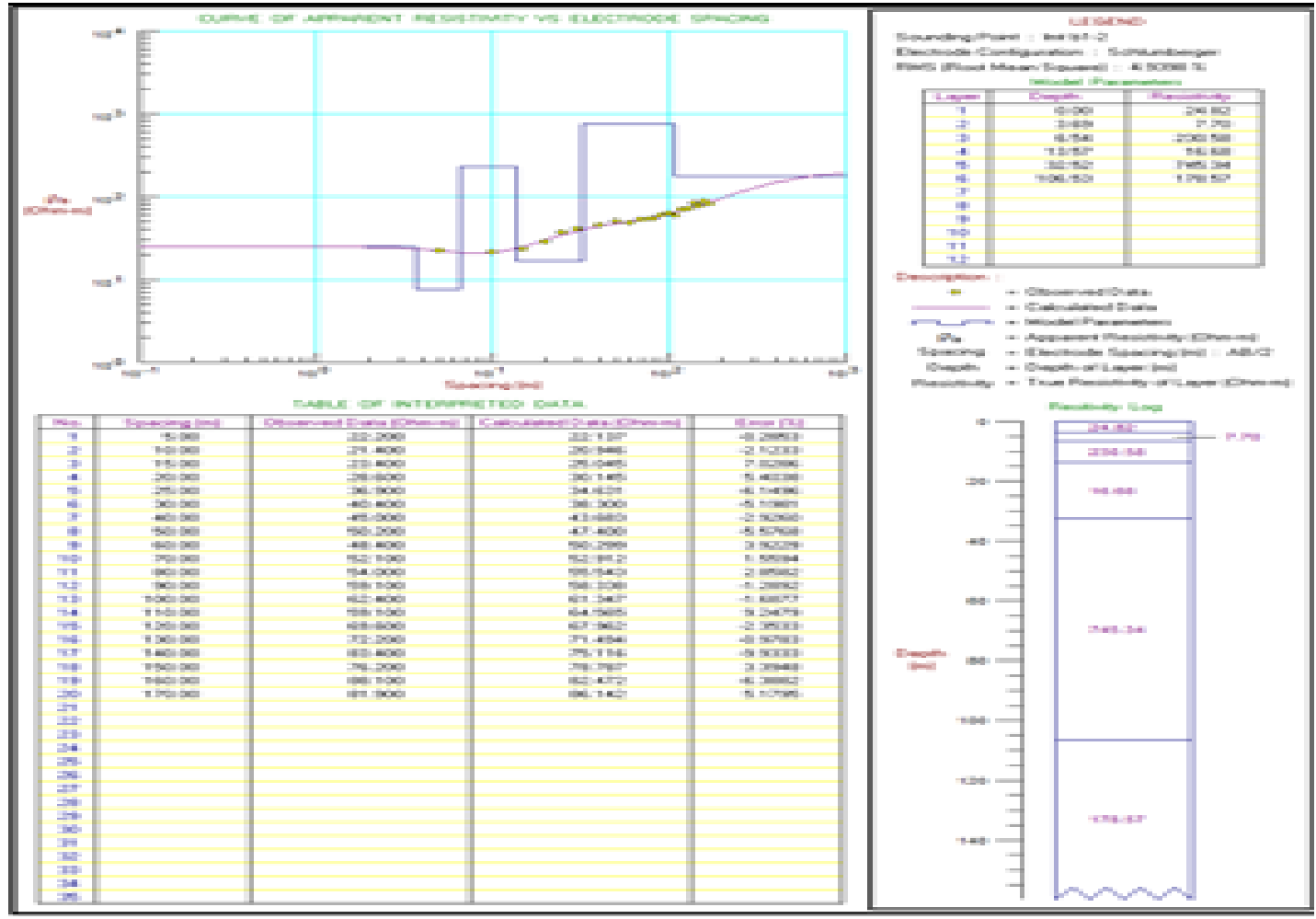


Tabel 9. Hasil Pengukuran Geolistrik Daerah Dadahup A5-1

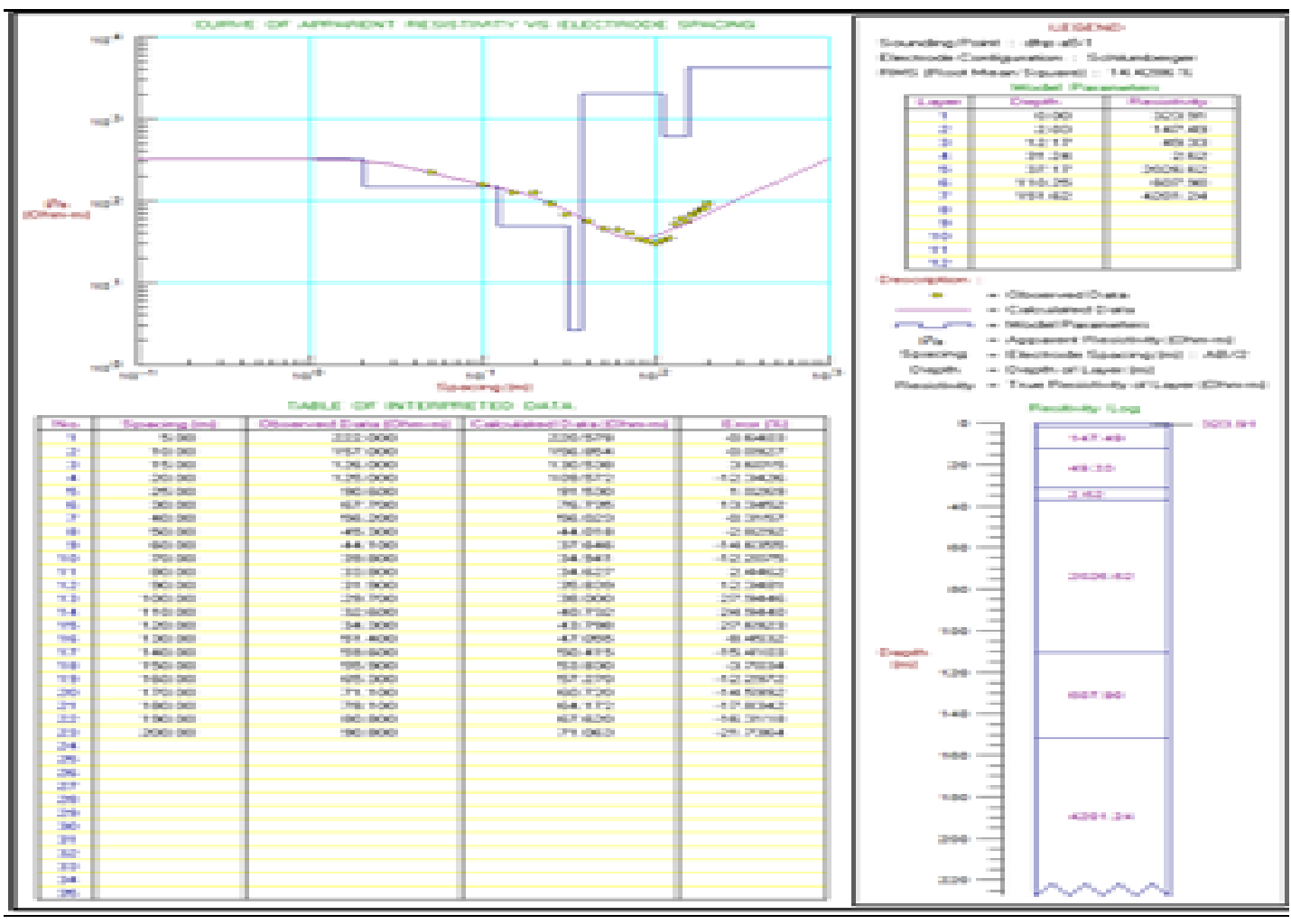

Tabel 10. Hasil Pengukuran Geolistrik Daerah Dadahup A5-2

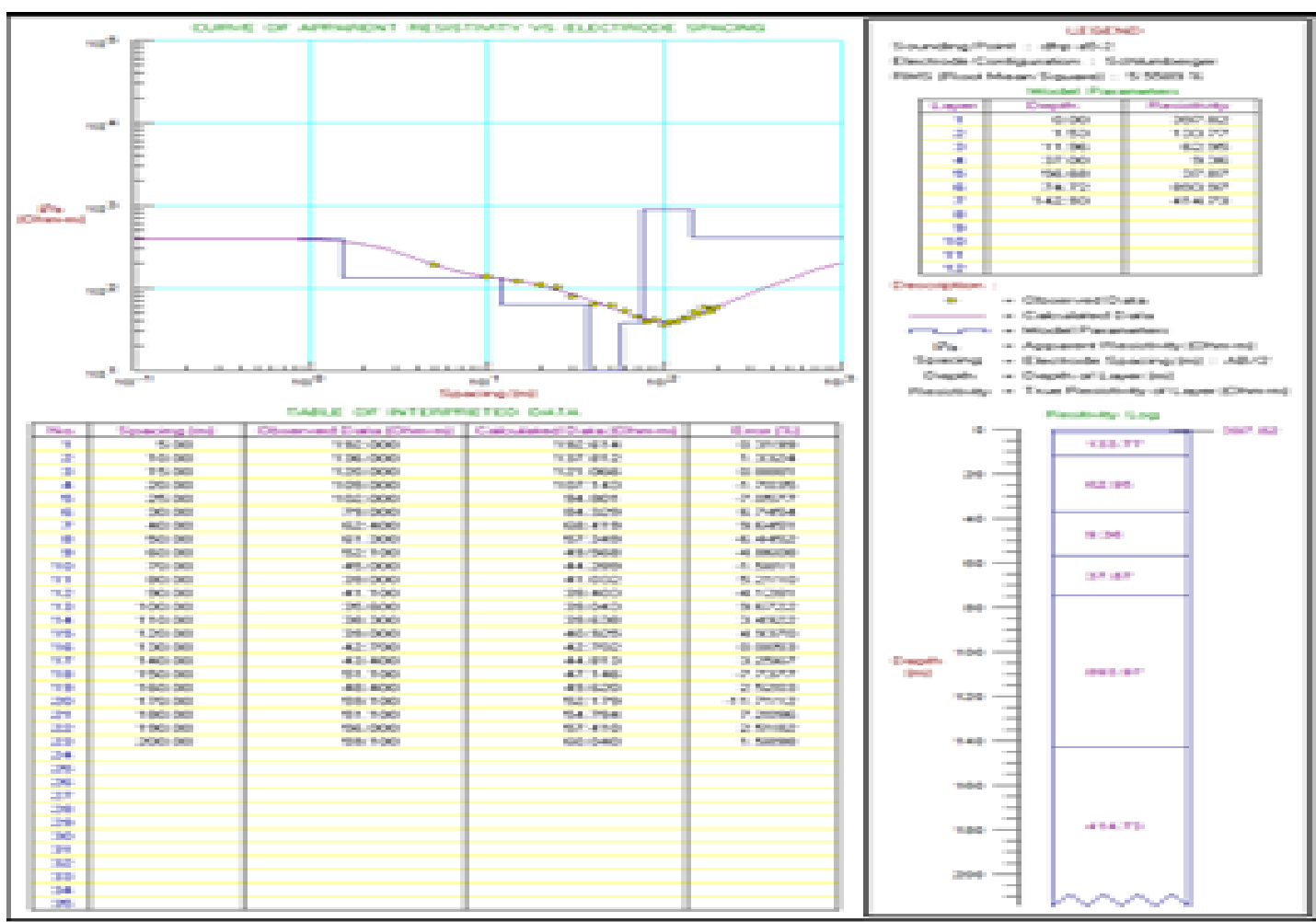


Jurnal Aplikasi Teknik Sipil ISSN.1907-753X

Tabel 11. Hasil Pengukuran Geolistrik Daerah Bungai Jaya (BSR1)

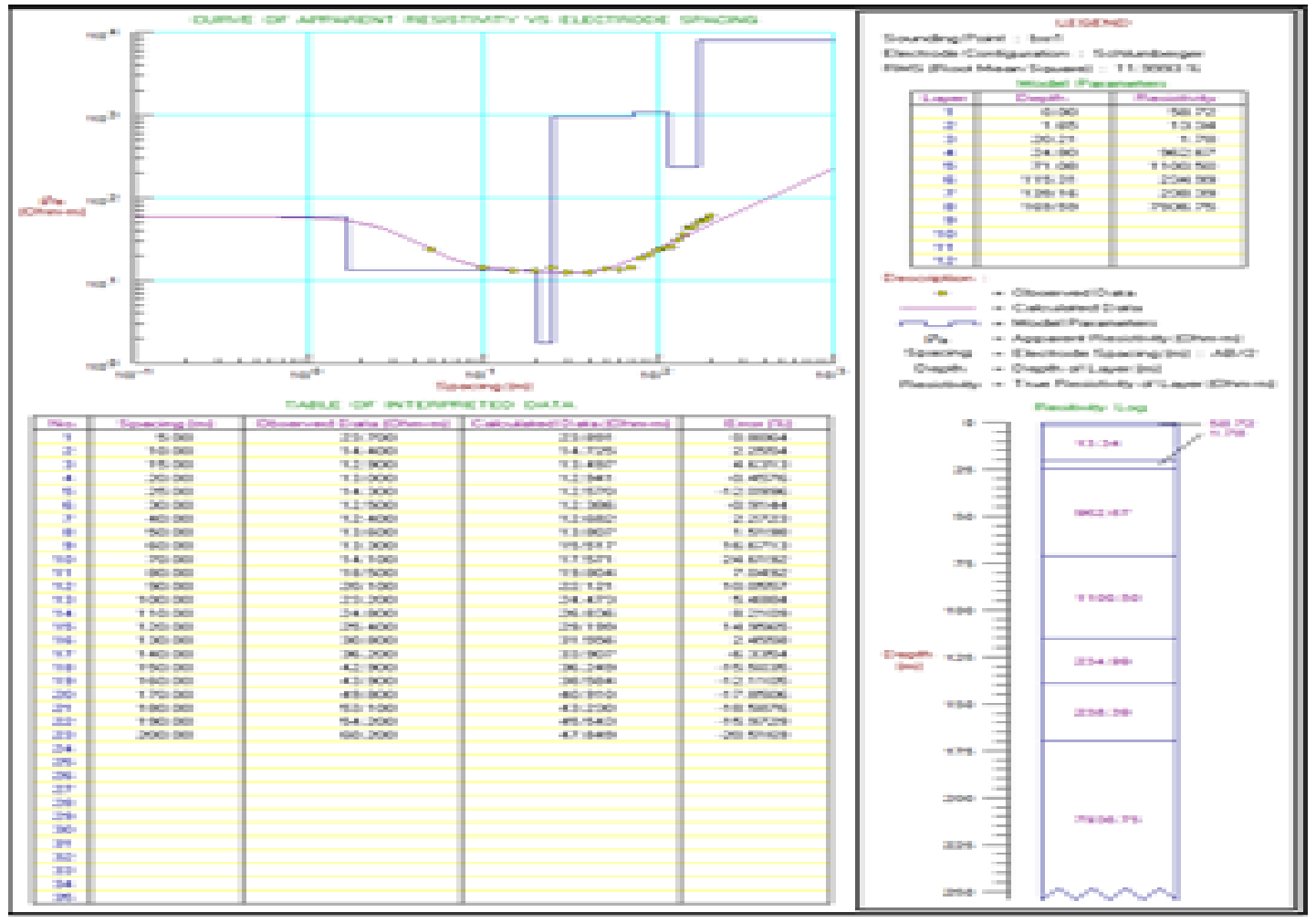

Tabel 12. Hasil Pengukuran Geolistrik Daerah Bungai Jaya (BSR2)

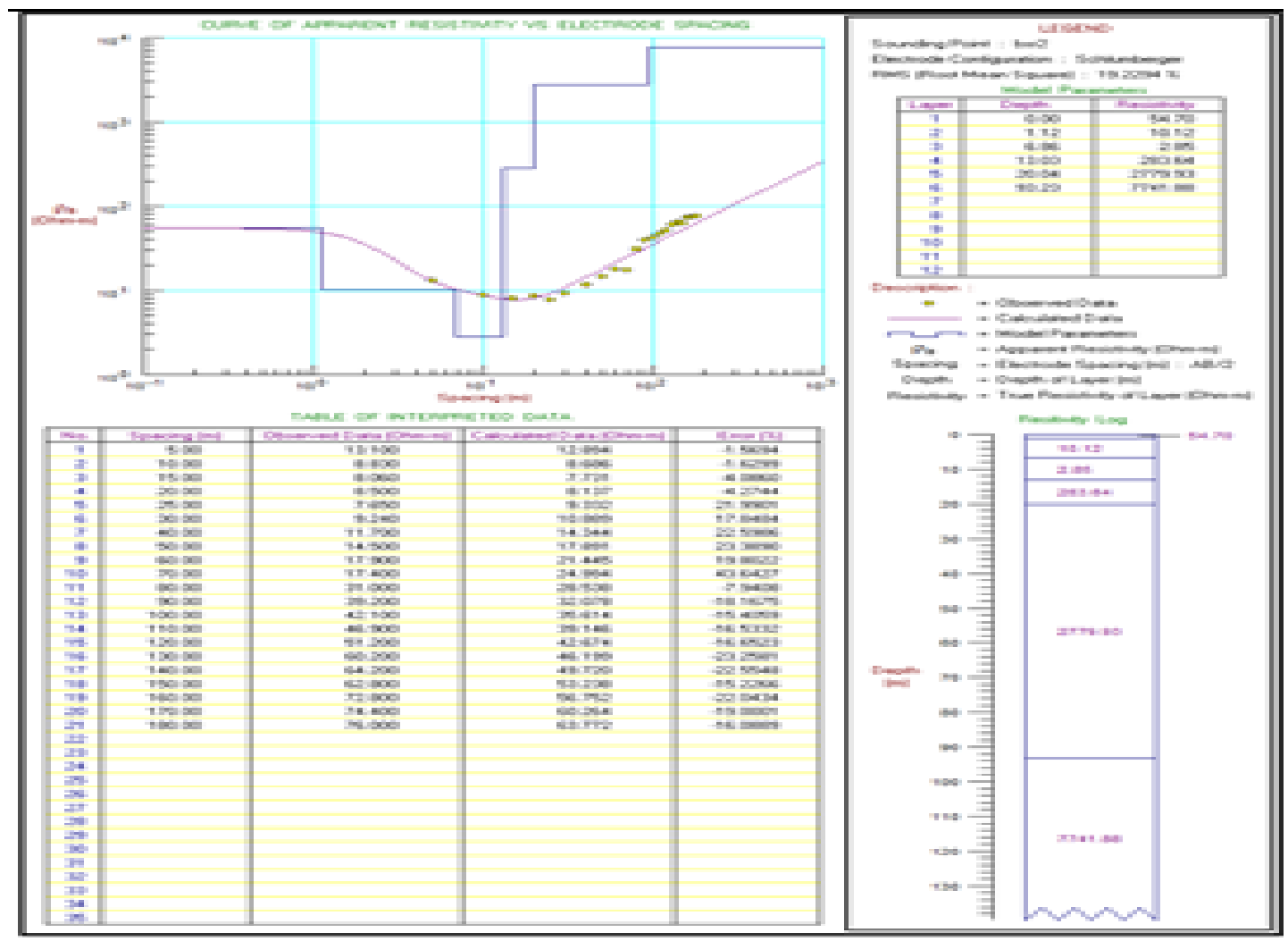


Tabel 13. Hasil Pengukuran Geolistrik Daerah Palingkau 1

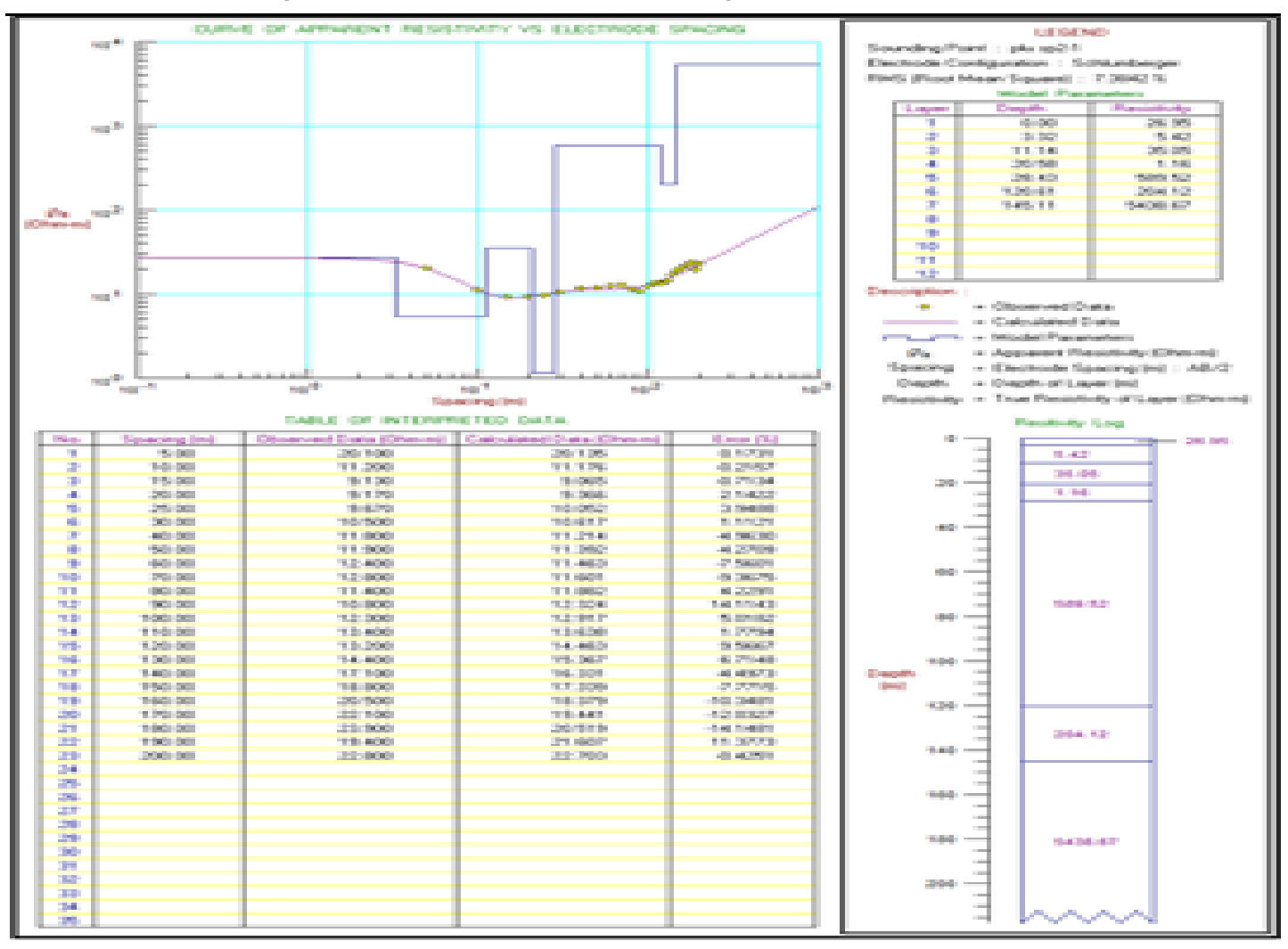

Tabel 14. Hasil Pengukuran Geolistrik Daerah Palingkau 2

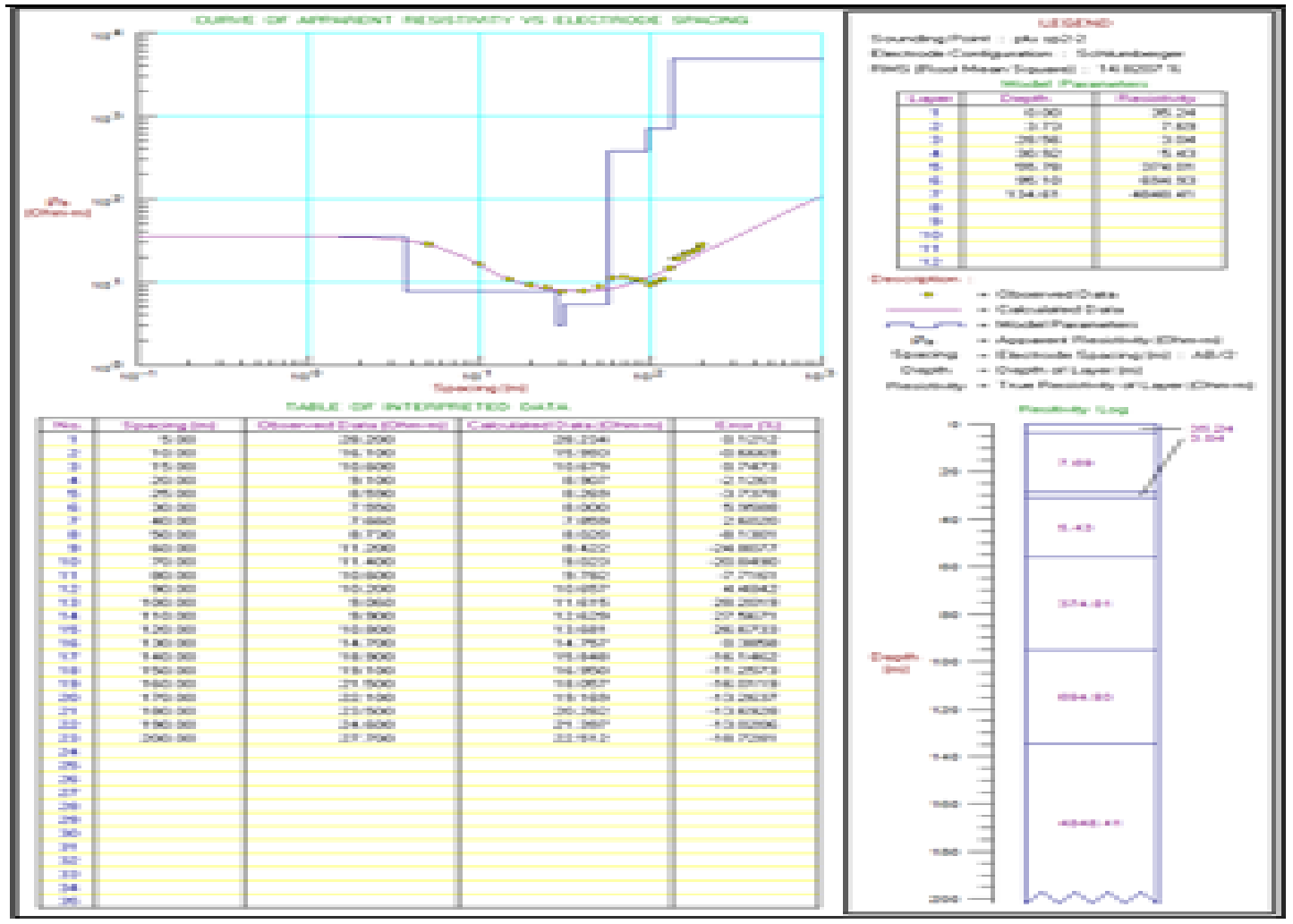




\section{ISSN.1907-753X}

Pada Tabel 1 - 14 dapat dijelaskan bahwa:

- Litologi batuan lokasi Batuah tersusun atas lumpur, lempung, pasir, kerakal, dan batuan bongkahan (boulder). Lapisan akuifer yang baik pada daerah ini adalah pasir yang diidentifikasi pada titik Batuah 1. Sedangkan titik Batuah 2 tidak diidentifikasi adanya lapisan akuifer. Pada Batuah 1 lapisan akuifer diidentifikasi pada kedalaman 121,4 sampai 150,27 meter; ketebalan lapisan 28,87 meter; nilai resistivitas batuan $94,78 \Omega \mathrm{m}$; tipe akuifer tertekan dengan lapisan kedap bagian atas batuan kerakal dan lapisan kedap bagian bawah batuan bongkahan lepas; transmisivitas $0,00401 \mathrm{~m}^{2} / \mathrm{det}$ dan debit potensial 1,921 L/det.

- Litologi batuan lokasi Lamunti B2 tersusun atas lempung, lanau pasiran, kerikil, gambut, dan kerakal. Lapisan akuifer yang baik pada daerah ini adalah lanau pasiran dan kerikil/gambut yang diidentifikasi pada titik Lamunti B2-1dan B2-2. Pada lamunti B2-1 lapisan akuifer diidentifikasi pada kedalaman 0,65 sampai 30,20 meter; ketebalan lapisan 29,55 meter dan debit potensial $0,409 \quad 1 /$ det sedangkan pada kedalaman 85,31 sampai 220 meter; ketebalan lapisan 134,69 meter dan debit potensial 1,865 L/det. Total debit potensial yang dimiliki oleh titik Lamunti B2-1 sebesar 2,27 L/det.

Pada lamunti B2-2 lapisan akuifer diidentifikasi pada kedalaman 12,95 sampai 38,22 meter; ketebalan lapisan 25,27 meter; dan debit potensial $0,799 \quad 1 /$ det sedangkan pada kedalaman 74,82 sampai 96,25 meter; ketebalan lapisan 21,43 meter; dan debit potensial 0,297 L/det. Total debit potensial yang dimiliki oleh titik Lamunti B2-2 sebesar 1,09 1/det.

- Litologi batuan lokasi Lamunti A2 tersusun atas lempung, lanau pasiran, dan kerakal. Lapisan akuifer yang baik pada daerah ini adalah lanau pasiran dan pasir yang diidentifikasi pada titik Lamunti A2-1dan A2-2. Pada Lamunti A2-1 lapisan akuifer diidentifikasi pada kedalaman 9,57 sampai 31,95 meter; ketebalan lapisan 22,38 meter; dan debit potensial 0,31 1/det. Sedangkan pada lamunti A2-2 lapisan akuifer diidentifikasi pada kedalaman 5,11 sampai 15,24 meter; ketebalan lapisan 10,13 meter; dan debit potensial 0,676 1/det. Dan debit potensial airtanah sebesar $0,310-0,6761 /$ det.

- Litologi batuan lokasi Lamunti B1 tersusun atas lempung, lanau pasiran, kerikil, gambut, dan kerakal. Lapisan akuifer yang baik pada daerah ini adalah lanau pasiran, pasir dan kerikil/gambut yang diidentifikasi pada titik Lamunti B1-1dan B1-2. Pada Lamunti B1-1 lapisan akuifer pada kedalaman 3,88 sampai 36,59 meter; ketebalan lapisan 32,71 meter dan debit potensial 0,453L/det. Serta kedalaman 58,87 sampai 163,90 meter; ketebalan 
lapisan 105,03 meter; dan debit potensial 1,46 1/det. Total debit potensial yang dimiliki oleh titik Lamunti B1-1 sebesar 1,9 1/det.

Pada lamunti B1-2 lapisan akuifer pada kedalaman 6,54 sampai 13,57 meter; ketebalan lapisan 7,03 meter; dan debit potensial 0,22 1/det. Serta pada kedalaman 106,53 sampai 140 meter; ketebalan lapisan 33,47 meter; dan debit potensial 2,227 1/det. Total debit potensial yang dimiliki oleh titik Lamunti B2-2 sebesar 2,45 L/det.

- Litologi batuan lokasi Dadahup tersusun atas lempung, lanau pasiran, pasir, kerakal, dan batuan bongkahan lepas. Lapisan akuifer yang baik pada daerah ini adalah lanau pasiran yang diidentifikasi pada titik Dadahup 1dan 2. Pada Dadahup 1 lapisan akuifer pada kedalaman 12,17 sampai 31,24 meter; ketebalan lapisan 19,07 meter dan debit potensial 0,265 $1 /$ det.

Pada Dadahup akuifer diidentifikasi pada kedalaman 11,96 sampai 37 meter; ketebalan lapisan 25,04 meter dan debit potensial $0,351 /$ det. Serta kedalaman 56,68 sampai 74,72 meter; ketebalan lapisan 18,04 meter debit potensial 0,25 1/det. Total debit potensial yang dimiliki oleh titik Dadahup 2 sebesar 0,590 1/det.

- Litologi batuan lokasi Bungai Jaya 1 dan 2 tersusun atas lempung, kerikil, gambut dan batuan bongkahan lepas (Boulder). Lapisan akuifer yang baik pada daerah ini adalah kerikil atau gambut (peat) diidentifikasi pada titik Bungai Jaya 1dan 2. Pada Bungai Jaya 1 lapisan akuifer pada kedalaman 115,31 sampai 169,59 meter; ketebalan lapisan 54,28 meter dan debit potensial 1,72 $1 /$ det.

Pada Bungai Jaya 2 lapisan akuifer pada kedalaman 13,03 sampai 20,04 meter; ketebalan lapisan 7,01 meter dan debit potensial 0,22 1/det.

- Litologi batuan lokasi Palingkau tersusun atas lempung, lanau pasiran, kerikil, kerakal, dan batuan bongkahan lepas. Lapisan akuifer yang baik pada daerah ini adalah lanau pasiran dan kerikil yang diidentifikasi pada titik Palingkau 1, sedangkan titik Palingkau 2 tidak diidentifikasi adanya lapisan akuifer.

Pada Palingkau 1 lapisan akuifer pada kedalaman 11,14 sampai 20,58 meter; ketebalan lapisan 9,44 meter dan debit potensial $0,13 \mathrm{l} / \mathrm{det}$. Serta pada kedalaman 120,61 sampai 145,11 meter; ketebalan lapisan 24,50 meter dan debit potensial 0,78 1/det. Total debit potensial yang dimiliki oleh titik Palingkau 1 sebesar 0,90 1/det.

\section{Simpulan}

Berdasarkan hasil pemetaan geolistrik pada Daerah Batuah, Lamunti, Dadahup, Bungai Jaya, dan Palingkau menunjukan potensinya sebagai berikut:

1. Daerah Batuah mempunyai kedalaman akuifer Antara 121,4 m sampai dengan 150,27 m mempunyai potensi debit $1,92 \mathrm{l} / \mathrm{dt}$. 
2. Daerah Lamunti B mempunyai dua lapisan akuifer dengan potensi air tanah yang dapat dikembangkan Antara $1.09 \mathrm{lt} / \mathrm{dt}$ sampai dengan $2.27 \mathrm{lt} / \mathrm{dt}$ sedangkan Daerah Lamunti A mempunyai potensi sebesar 0,31 lt/tsampai dengan 0,676 lt/dt

3. Daerah Dadahup mempnyai potensi air tanah sebesar $0.265 \mathrm{lt} / \mathrm{dt}$ sampai dengan $0.59 \mathrm{lt} / \mathrm{dt}$.

4. Bungai Jaya mempunyai potensi air tanah sebesar $0.222 \mathrm{lt} / \mathrm{dt}$ sampai dengan $1.715 \mathrm{lt} / \mathrm{dt}$.

5. Palingkau mempunyai potensi air tanah sebesar 0.9 lt/dt.

\section{Daftar Pustaka}

Anderson. 1993. Introduction to Groundwater Modeling, Finite Difference and Finite Element Methods.

Bisri, M., 2010. Air Tanah. Malang: Tirta Media, Universitas Brawijaya.

Hindarko S., 2002. Manfaatkan Air Tanah Tanpa Merusak Kelestariannya, Seri Lingkungan Hidup. Penerbit ESHA,

Kumar, C.P., Groundwater Data Requirement and Analysis, National Institute of Hydrology, Roorkee.

Munir Moch., 2003. Geologi Lingkungan. Bayumedia Publising, Juli.

R. Allan Freezer \& John A. Cherry. 1979. Groundwater, Department of Geological Sciences. Univer- sity of Britis Columbia, Vancouer, British Columbia.

Sihwanto. 1991. Parameter Akuifer dan Aliran Air Tanah Diklatsar Hidrogeologi Kanwil Pertambangan dan Energi, Direktorat Geologi Tata Lingkungan Dirjen Geologi dan Sumberdaya Mineral, Dept. Pertambangan dan Energi Republik Indonesia

Sosrodarsono, S., dan Takeda, K., 1976. Hidrologi untuk Pengairan. Jakarta: Pradnya Paramitha.

Todd, D.K., 1980. Groundwater Hydroloy. $2^{\text {nd }}$ Edition, John Wiley \& Sons, New York, Chichester, Brisbane, Toronto. 
